\title{
SELECTED ASPECTS OF REGIONAL UNEMPLOYMENT DIFFERENTIATION IN SLOVAKIA
}

\author{
[Vybrané aspekty regionální diferenciace nezaměstnanosti na Slovensku] \\ Eva Rievajová ${ }^{1}$, Petr Zadražil ${ }^{2}$ \\ ${ }^{I}$ Ekonomická univerzita v Bratislave, Národohospodárska fakulta, Dolnozemská cesta 1, 85235 Bratislava \\ Email:eva.rievajova@euba.sk \\ ${ }^{2}$ Ekonomická univerzita v Bratislave, Národohospodárska fakulta, Dolnozemská cesta 1, 85235 Bratislava \\ Email:petr.zadrazil@euba.sk
}

\begin{abstract}
Relatively higher unemployment rate in compare with other European countries is a persisting problem of Slovak republic, and distribution of unemployment is significantly differentiated in space. This paper aims to research on selected aspects of regional differences in unemployment in Slovakia, such as gender, age and education level, and to link local unemployment rates to wage levels. Analysis is used as a key method, focusing on statistical data of 2015 registered unemployment from the Central Office of Labour, Social Affairs and Family. Among the key findings, our research confirms growing rates of unemployment on axis west-east in general, with higher internal differences in regions with higher rates. While gender differences are not significant, education shows as an important factor for labour market position, and we confirm high youth unemployment rate in some regions. In the last part of the paper, we relate local unemployment rates with wage levels to show the impact of unemployment on income level.
\end{abstract}

Keywords: disparities, minimum wage, regional differentiation, unemployment.

JEL classification: J16, J21, J64

Doručeno redakci: 18.4.2016; Recenzováno: 26.4.2016; 13.7.2016; Schváleno k publikování: 24.8.2016

\section{Úvod}

Slovensko je v evropském srovnání státem s vyšší mírou nezaměstnanosti, která je navíc dlouhodobě výrazně prostorově diferencovaná na ose západ - východ. Cílem př́spěvku je prostřednictvím analýzy zhodnotit vybrané aspekty regionálních rozdílů v nezaměstnanosti, zejména $v$ její struktuře, tedy podle věku, pohlaví a vzdělání. Problematiku nezaměstnanosti nejprve uvedeme $\mathrm{v}$ rovině teoretických koncepcí $\mathrm{z}$ prací vybraných autorů. $\mathrm{V}$ druhé části provedeme výzkum nezaměstnanosti v krajích a okresech Slovenska v roce $2015 \mathrm{v}$ členění podle vybraných kličových kategorií, tedy podle pohlaví, věku, se zaměřením na nezaměstnanosti mladých do 25 let, a podle vzdělání, a v poslední části budeme věnovat pozornost relaci nezaměstnanosti a mezd s akcentem na vlivy minimální mzdy na lokální trhy práce.

Data zkoumáme na úrovni Slovenska, krajů a okresů. Zejména v př́́padě krajů pracujeme s jednotkami, u kterých jde jen o administrativní vymezení. Současné krajské členění na Slovensku př́liš nerespektuje historické ani ekonomické vazby a není možné definovat kraje ve smyslu vnitřní homogenity a vnější odlišnosti mezi regiony navzájem. Pro analýzu nezaměstnanosti jsme použili data statistik ÚPSVaR (Ústredie práce, sociálnych vecí a rodiny, 2016) o uchazečích o zaměstnávání za jednotlivé měsíce v roce 2015, přepočítaná na celý rok aritmetickým průměrem jednotlivých koncoměsíčních pozic. Pokud hovoříme o miře nezaměstnanosti, pracujeme $\mathrm{v}$ souladu $\mathrm{s}$ metodikou ÚPSVaR s podílem disponibilních uchazečů o zaměstnání na celkové ekonomicky aktivní populaci. Strukturu nezaměstnaných zkoumáme na celkovém počtu uchazečù o zaměstnání $\mathrm{v}$ evidenci, tedy včetně 
nedisponibilních. Doplňujícím zdrojem dat jsou údaje ŠÚ SR (Štatistický úrad Slovenskej republiky, 2016a-c), zejména výsledky výběrových zjišt'ování pracovních sil, které se odlišují metodikou od údajů o evidované nezaměstnanosti, základní rozdíl je v povaze nezaměstnanosti, kdy Statistický úřad pracuje s deklarovanou nezaměstnaností s úplnou absencí práce, zatímco Ústředí práce s evidovanou nezaměstnaností s možností pracovní činnosti pod stanovenou př́jmovou hranicí. K doplnění některých charakteristik aplikujeme i data z výsledků Sčítání obyvatel, domů a bytů z roku 2011 (Štatistický úrad Slovenskej republiky, 2016d). Pro evropské statistiky využíváme data z Eurostatu (2016a,b), která vycházejí z metodiky používané i Statistickým úřadem. K označení zkratek okresů v obrázcích používáme označení evidenčních čísel motorových vozidel pro jednotlivé okresy (Slovensko.sk), zkratky krajů odpovídají normě ISO 3166-2 podle UNECE.

\section{Teoretická východiska výzkumu nezaměstnanosti a její prostorové diferenciace}

Nezaměstnanost jako nerovnováha trhu práce je závažným ekonomickým problémem s přesahem do sociální sféry. Existence nezaměstnanosti je průvodním jevem na trhu práce v podmínkách tržní ekonomiky (Rievajová a kol., 2012, s. 200), i v její sociálně-tržní podobě garantované Ústavou Slovenské republiky. Z ekonomického pohledu představuje nesoulad nabídky a poptávky na trhu práce, který může mít různé příčiny. Trh práce má dvojitý alokační mechanismus, umist’uje pracovní sílu v procese produkce a zároveň rozděluje část produkce jako odměnu ve formě mzdy, platí na něm zákonitosti jako na jiných trzích, má ale svá významná specifika, vycházející zejména $z$ faktu, že práce se neoddělitelně váže na nositele - konkrétního člověka se všemi jeho odlišnostmi od jiných souborem schopností, vědomostí a zručností, tedy vybaveností lidským kapitálem.

Regionální nezaměstnanost je formou strukturní nezaměstnanosti, dochází k ní při nerovnováze nabídky a poptávky na trhu práce $\mathrm{v}$ prostoru. Jako celek se v evropských statistikách nezaměstnanosti pohybuje Slovensko i přes nedávné zlepšení své pozice na posledních místech, ale s výraznou prostorovou diferenciací. Typickou charakteristikou slovenského trhu práce je rostoucí nezaměstnanost na ose západ - východ, která vede ke koncentraci nezaměstnanosti a chudoby $\mathrm{v}$ některých oblastech středního a východního Slovenska. Jde o důsledek odlišného demografického, ekonomického, technického a dalšího potenciálu ve spojení s geografickými danostmi. Tyto charakteristiky podmiňovaly vývoj, zejména prŕliv zahraničních investic směřující převážně na západ země, který diferenciaci regionů dále zvyšoval.

Paukovič (2007, s. 73-74) uvádí, že současná regionální diferenciace nezaměstnanosti byla daná situací př̀ed rokem 1989, zejména v důsledku regionální jednoodvětvové industrializace, neudržitelné struktury regionálního hospodářství a přezaměstnanosti doplněné nízkou adaptabilitou pracovní síly. Vysoká nezaměstnanost se v některých regionech objevila hned se začátkem transformace, v pozdějších letech ji zvýšila zadluženost a platební neschopnost některých podniků. Mezi současné prŕíčiny nezaměstnanosti podle autora patří rigidita trhu práce, přetrvávající diskriminace ve vazbě na etnikum, mateřství, předdůchodový věk nebo diskriminace absolventů bez praxe a nedostatečná nebo nevhodná kvalifikační úroveň uchazečů o zaměstnání. Jednotlivé aspekty nezaměstnanosti si zasluhují pozornost pro specifické okolnosti, které je provázejí.

Nezaměstnanost žen je nutné vnímat ve vazbě na jejich celkově nižší participaci na trhu práce, která vypovídá mimo jiné i o nedostatečných možnostech harmonizace rodinného a pracovního života. Vyšší míra nezaměstnanosti žen je potom možným indikátorem diskriminačního chování zaměstnavatelů. Výrazně negativním jevem je nezaměstnanost 
mladých lidí, nejen z ekonomického, ale i sociálního hlediska. Ekonomika ztrácí prostředky investované ve vzdělávacím procese do tvorby lidského kapitálu mladých nezaměstnaných, zejména vysokoškolsky vzdělaných. Nejzávažnější jsou sociální důsledky nezaměstnanosti u této skupiny, mladým lidem bez příjmu existenční nejistota brání osamostatnit se, kvůli čemu často odsouvají založení rodiny do vyššího věku. Problémem je nemožnost získat pracovní návyky a hlavně praxi, kterou zaměstnavatelé vyžadují, vedle absence praxe může být prŕčinou nezaměstnaností mladých lidí i nesoulad jejich kvalifikace s potřebami zaměstnavatelů vyplývající ze slabé vazby vzdělávacího systému na trh práce, případně nereálná očekávání samotných uchazečů o zaměstnání na pracovní podmínky, mzdu a zaměstnanecké benefity.

Pozice člověka na trhu práce je do velké míry ovlivněná jeho specifickým lidským kapitálem. Statisticky je obtížné kvantifikovat přesný soubor znalostí, schopností a dalších osobnostních charakteristik, základní kvalifikaci člověka a jeho potenciálu na pracovním trhu však dobře vyjadřuje vzdělanostní úroveň v podobě nejvyššího ukončeného stupně vzdělání. V tomto smyslu skladba nezaměstnanosti podle stupňủ vzdělání ukazuje na strukturní nesoulad mezi vzdělávacím systémem a potřebami trhu práce. Vliv dosaženého vzdělání je možné stručně vyjádřit tak, že s vyšším dosaženým stupněm klesá riziko nezaměstnanosti. Schultz (1961) ve své práci studoval důležitost investic do lidského kapitálu při ekonomickém rozvoji země. Zjistil, že tento druh investic dosahuje nejvyšší míry výnosnosti, proto by se na tento zdroj ekonomického růstu měly zaměřit především chudé (resp. rozvojové) země a regiony a neměly by vzdělání a školní docházku chápat jen jako spotřební zboží.

V případě nezaměstnanosti ale nejde jen o její ekonomický rozměr, vazbou na konkrétní osoby určuje jejich pozici a status ve společnosti, které s absencí pracovního př́ijmu klesají. Mzdy jsou nejdůležitějších zdrojem prŕjmů slovenských domácností, v domácnostech ekonomicky aktivních jsou zdrojem hlavním, nezaměstnanost tak má vliv na př́jmové postavení rodin i jednotlivců. Období, kdy je člověk bez zaměstnání, se projevuje výrazným propadem př́jmů a tím i životní úrovně. Nejistá budoucnost a další atributy nezaměstnanosti však mají významné přesahy i na sociální sféru. Mareš (1994, s. 56) popisuje centrální roli práce v životě člověka a společnosti a nezaměstnanost pak vnímá jako deprivaci základních potřeb, a to jak spotřebě, tak sociální participaci.

Přestože nízká mzdová úroveň je jedním z kritérií při rozhodování investorů o lokalizaci investic, výhoda nízké ceny práce $\mathrm{v}$ periferních oblastech je převýšena negativy - problémem periferních oblastí je nedostatečná infrastruktura, slabé napojení na hlavní dopravní cesty a zaostávající kvalifikace pracovní síly. Svou roli na nepříznivém vývoji v některých regionech hraje i celková nízká míra územní mobility pracovní síly.

V současnosti často diskutovaným fenoménem je institut minimální mzdy. Čaplánová a Martincová (2014, s. 43) k problematice minimální mzdy a jejího vlivu na nezaměstnanost konstatují, že neexistuje shoda ohledně dopadů minimální mzdy na zaměstnanosti, podle některých autorů vysoká minimální mzda demotivuje zaměstnavatele od zaměstnávání nových pracovníků zejména $\mathrm{v}$ odvětvích s převažující minimální mzdou, podle jiných autorů ale může mít institut minimální mzdy pozitivní vliv na zaměstnanost. Institut finanční politiky (2016, s. 4) ve své studii uvádí, že „Převážná část výzkumů, které identifikují negativní vliv minimální mzdy na zaměstnanost, se zabývá skupinou mladých a málo kvalifikovaných pracovniku (Currie a Fallick, 1996; Neumark a Wascher, 2007; Herr et al., 2013; Neumark et al., 2013). Efekt může být statisticky významný v určitých odvětvích s vyšším podílem málo kvalifikovaných pracovních pozic, a odlišný v závislosti na ekonomické vyspèlosti regionu. 
Minimální mzda může mít dokonce i pozitivní vliv na zaměstnanost, z důvodu zvýšení pracovnich motivací na straně nabídky práce (Schmitt, 2013). Literatura reflektuje relativně široký konsenzus v kontextu vztahu minimálni mzdy a př́jmových nerovností. Nárůst minimální mzdy se projevuje ve změně př́jmové distribuce ve prospěch nízkoprijimových zaměstnanců. (Herr et al., 2013). “ Názory na vliv minimální mzdy tedy nejsou jednoznačné.

\section{Regionální a lokální míry nezaměstnanosti v roce 2015}

Obrázek 1 ukazuje vývoj regionální míry nezaměstnanosti vposledních 15 letech. Ekonomické problémy konce 90 . let se projevovaly na trhu práce vysokou nezaměstnaností, kterou se úspěšně dařilo kontinuálně snižovat. Zcela nejnižších hodnot dosáhla ve všech krajích za sledované období v roce 2007. Zlom nastal příchodem ekonomické krize na přelomu let 2008 a 2009, při které nezaměstnanost opět narostla ve všech regionech, ale na nižší hodnoty než v roce 2001 . Nejvyšších hodnot v tomto období dosáhla téměř ve všech krajích v roce 2012, pouze $\mathrm{v}$ Bratislavském kraji byla ještě vyšší o rok později. Pokrizový pokles míry nezaměstnanosti však stále nedosáhl hodnot roku 2007. Obrázek dále ukazuje relativně stálé postavení jednotlivých regionů v čase, ekonomické procesy se na trhu práce replikují poměrně rovnoměrně a pořadí jednotlivých krajů se významněji nemění. Bratislavský kraj si dlouhodobě udržuje nejnižší míru nezaměstnanosti, Bratislavský, Trnavský a Trenčínský kraj se trvale drží pod slovenským průměrem, naopak kraje východního Slovenska a Banskobystrický kraj vykazují výrazně vysokou nezaměstnanost. Pozitivní je zlepšení pozice Nitranského kraje, kde míra nezaměstnanosti klesla z vysoké výchozí pozice pod slovenský průměr. Zejména po roce 2012 je pak patrná vedle celkového poklesu určitá konvergence míry nezaměstnanosti do dvou skupin na ose západ-východ, tedy kraje na západě s mírou nezaměstnanosti pod slovenským průměrem a kraje na východě nad ním.

Obrázek 1: Vývoj míry nezaměstnanosti v krajích mezi roky 2001 a 2015

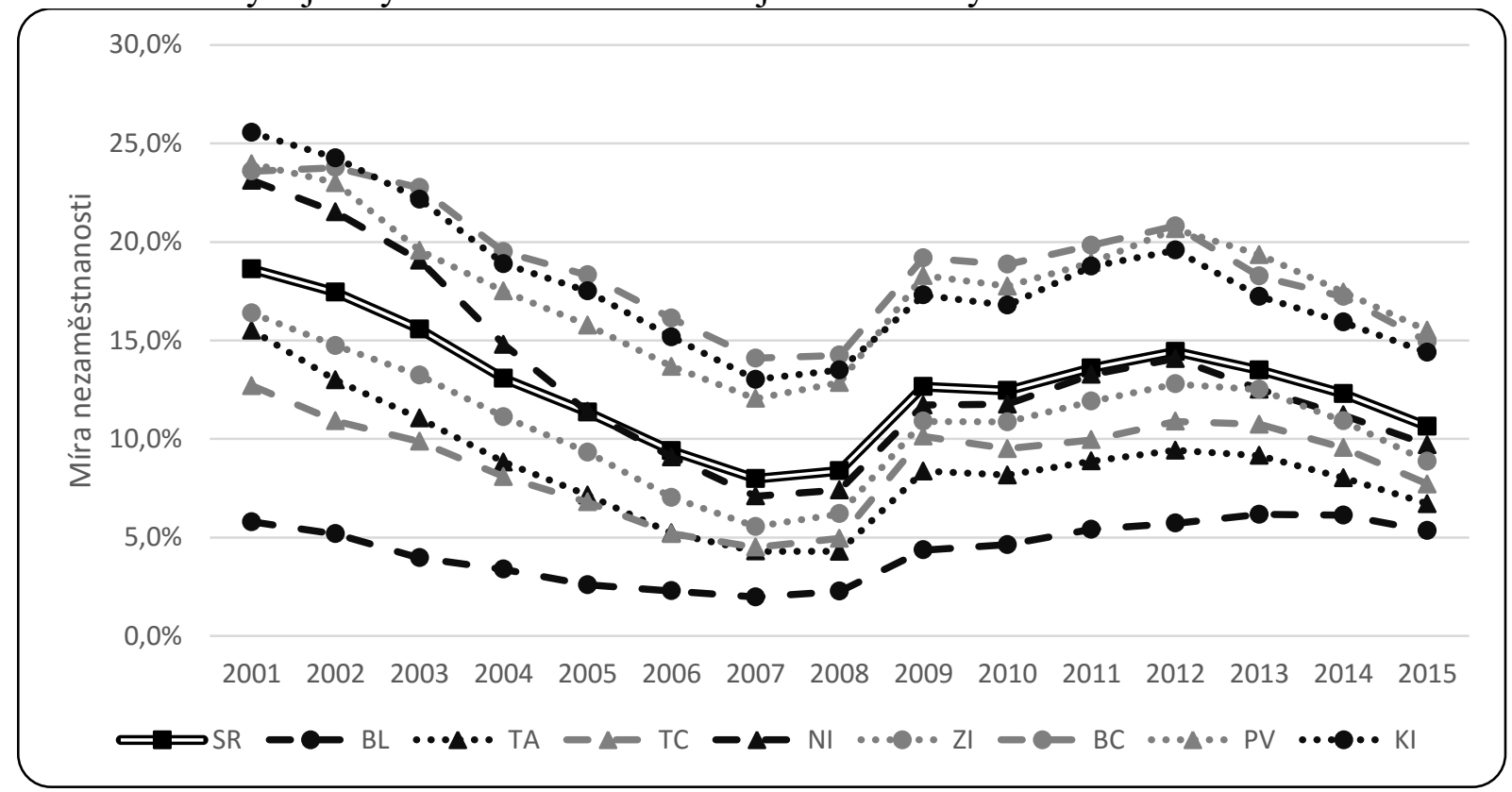

Zdroj: Štatistický úrad Slovenskej republiky: Databáza DATAcube: Miera evidovanej nezamestnanosti [online] [vid. 14. července 2016]. Dostupné z: datacube.statistics.sk/TM1WebSK/TM1WebLogin.aspx 


\subsection{Nezaměstnanost podle pohlaví}

Aritmetickým průměrem stavů nezaměstnanosti na konci měsíce ze statistik Ústředí práce, sociálních věcí a rodiny jsme vypočítali hodnoty evidované nezaměstnanosti pro rok 2015 za jednotlivé kraje a okresy. Celková míra nezaměstnanosti na Slovensku v tomto roce byla $11,5 \%$ a pod touto hodnotou se pohybovaly všechny kraje západního Slovenska, Bratislavský kraj s nejnižší hodnotou 5,8 \%. Kraje východního Slovenska a Banskobystrický kraj dosahovaly s odstupem hodnot nad průměrem za celou republiku. Zcela nejvyšší míru evidované nezaměstnanosti 16,5 \% vykazoval Prešovský kraj.

Obrázek 2: Okresy s nejvyšší a nejnižší mírou evidované nezaměstnanosti v krajích v roce 2015

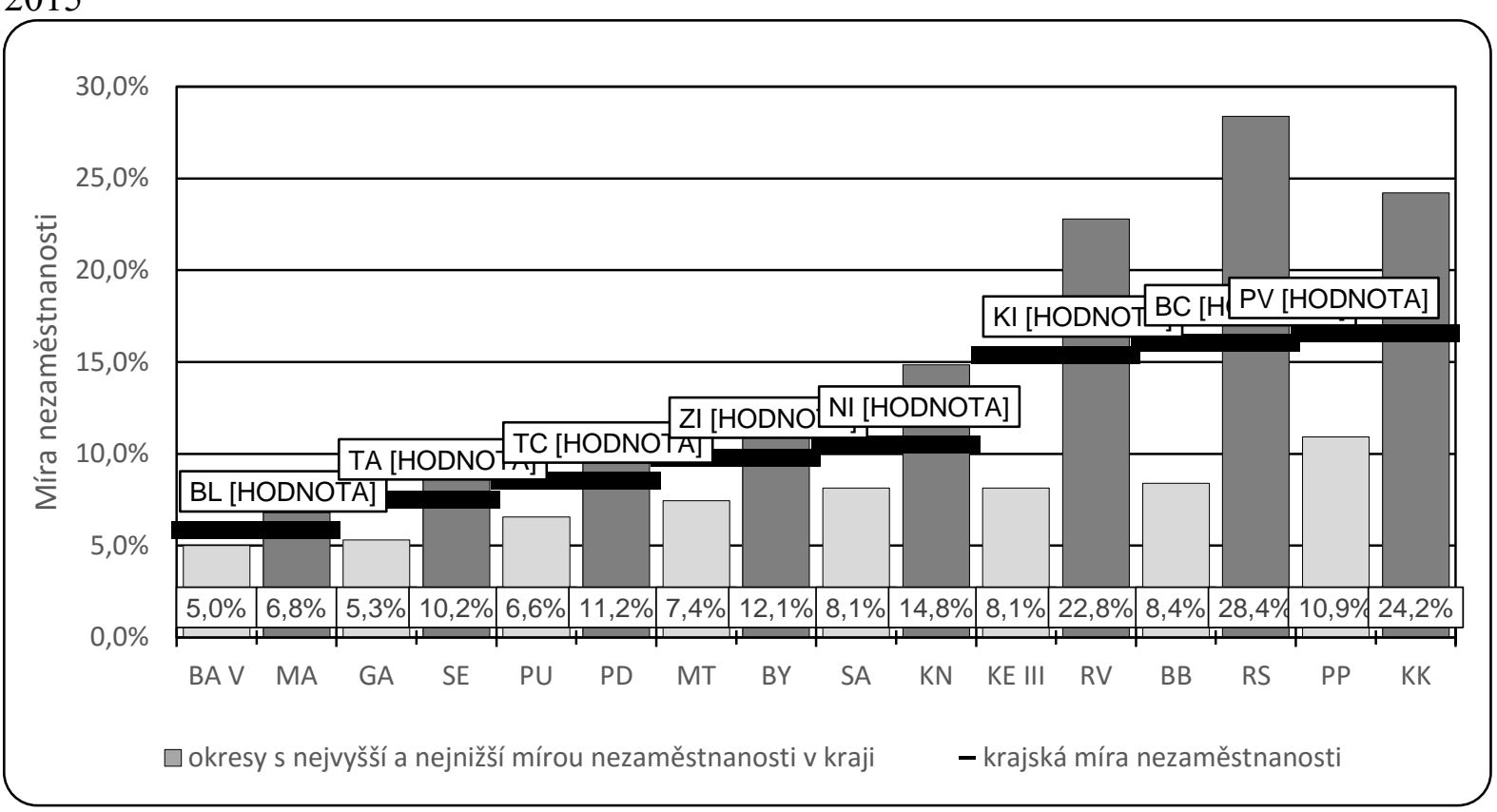

Zdroj: Ústredie práce, sociálnych vecí a rodiny: Nezamestnanost' - mesačné štatistiky [online] [vid. 28. února 2016]. Dostupné z: www.upsvar.sk/statistiky/nezamestnanost-mesacne-statistiky.html?page_id=1254

V rámci krajů však existují významné rozdíly, zejména $\mathrm{v}$ př́ípadě těch $\mathrm{s}$ vyšší celkovou mírou nezaměstnanosti, jak zobrazuje obrázek 2. V Bratislavském kraji byla variabilita mezi jednotlivými okresy malá, s rozdílem jen 1,8 \% mezi nejvyšší a nejnižší hodnotou, a městský okres Bratislava $\mathrm{V}$ byl okresem s vůbec nejnižší mírou evidované nezaměstnanosti na Slovensku. Ve skupině krajů západního Slovenska a v Žilinském kraji rozdíly narůstaly, např́íklad v Trnavské kraji byla $\mathrm{v}$ okrese Senica s nejvyšší nezaměstnaností její míra téměř dvojnásobná oproti okresu Galanta. V rámci těchto krajů byl největší podíl osob bez práce v okrese Komárno, 14,8 \%. V této skupině regionů je tedy patrná diferenciace nezaměstnanosti ve vazbě na geografickou polohu, profilují se okresy s ekonomickými centry a nižší mírou evidované nezaměstnanosti a okresy na periferii s vyšším podílem nezaměstnaných. Např́klad v Trenčínském kraji se nezaměstnanosti koncentruje v okresech Partizánske a Prievidza zatímco považské okresy vykazují lepší hodnoty, v Nitranském kraji jsou takovými ekonomickými centry Nitra a Šal'a a periferií jižní část kraje, v Žilinském kraji jsou ekonomicky výkonné okresy Martin a Žilina. Nejvyšší variabilita byla v jiho-východní skupině krajů, v Banskobystrickém, Prešovském a Košickém. Banskobystrický kraj je regionem s nejvyšší vnitřní variabilitou míry evidované nezaměstnanosti vůbec, pozice okresů s nejvyšší a nejnižší mírou se liší o 20 \%. Zatímco okresy Banská Bystrica a Zvolen jsou ekonomickými centry kraje a míra nezaměstnanosti v nich byla výrazně nižší, na jihovýchodní periferii kraje leží okresy s vůbec nejvyšší nezaměstnaností na Slovensku 
za rok 2015, Rimavská Sobota s 28,4 \% a Revúca s 24,4 \%. Prešovský kraj je jediným regionem, kde ve všech okresech překračovala míra nezaměstnanosti $10 \%$, a jediný okres Poprad dosahoval nižší hodnotu než slovenský průměr, nejhorší pozici měl okres Kežmarok, který byl ve slovenském srovnání okresem střetí nejvyšší mírou nezaměstnanosti. V Košickém kraji byla nezaměstnanosti výrazně nižšś ve všech městských okresech krajského města, které tvoří přirozené ekonomické centrum celého východního Slovenska, všechny ostatní okresy kraje ale vykazovaly výrazně nadprůměrnou nezaměstnanosti.

\subsection{Nezaměstnanost podle pohlaví}

Celkově je participace žen měřená jejich podílem na počtu všech ekonomicky aktivních nižší. V průměru na Slovensku připadalo na 100 ekonomicky aktivních mužů jen 82 žen, ale i u tohoto indikátoru jsou výrazné prostorové rozdíly, které však nemají prrímou vazbu na lokální úroveň nezaměstnanosti ani mezd. Vysoká participace je jak v bratislavských okresech s nejnižší celkovou nezaměstnaností, tak i v okrese Rimavská Sobota, kde je nezaměstnanost nejvyšší, indikátor je spíš diferencovaný na mimoekonomickém základě, okresy s vyšší mírou participace leží na západě a jihu Slovenska, nejnižší míra ekonomické participace žen je na severu, jen 65 žen na 100 mužů v okrese Námestovo, 69 v Bytči a 70 ve Tvrdošíně. Problémem je tak hlavně vyšší nezaměstnanost žen. V průměru byla na Slovensku míra evidované nezaměstnanosti žen vyšší o $2,1 \%$ než mužů. Jen ve dvou okresech byla naopak vyšší nezaměstnanost mužů, o 0,4 \% v okrese Krupina a $0,1 \%$ v Banské Bystrici. Vyšší byla nezaměstnanost žen ve všech ostatních 77 okresech, nejvyšší rozdíly nad $4 \%$ byly naměřeny celkem ve 14 okresech, s maximem 6,1 \% za okres Námestovo, kde bylo evidovaných mezi disponibilními uchazeči 8,4 \% ekonomicky aktivních mužů, ale 14,4 \% žen. Rozdíly se projevovaly i tak, že ve 4 okresech byla v př́ípadě mužů evidovaná nezaměstnanost pod $5 \%$, za okresy Bratislava I, IV, V a okres Galanta, v př́padě žen byly nejnižší hodnoty o jeden bod vyšší a jen dva okresy vykazovaly méně než $6 \%$, Bratislava I a V. Pozice okresů s nejvyšší a nejnižší nezaměstnaností podle pohlaví se př́liš neliší, jak naznačuje i tabulka 1 , a výrazně dobrá nebo špatná situace na trhu práce se rovnoměrně odráží na nezaměstnanosti obou pohlaví. Větší rozdíly jsou v okresech se střední hodnotou nezaměstnanosti a vážou se pravděpodobně na mimoekonomické faktory.

Tabulka 1: Tři okresy s nejvyšší a nejnižší evidovanou mírou nezaměstnanosti mužů a žen $\mathrm{v}$ roce 2015

\begin{tabular}{|l|c|l|c|}
\hline \multicolumn{2}{|c|}{ Muži } & \multicolumn{2}{c|}{ Ženy } \\
\hline Okres & Míra nezam. & Okres & Míra nezam. \\
\hline Bratislava V & $4,70 \%$ & Bratislava V & $5,40 \%$ \\
\hline Bratislava IV & $4,70 \%$ & Bratislava I & $5,80 \%$ \\
\hline Bratislava I & $4,80 \%$ & Bratislava IV & $6,00 \%$ \\
\hline & & & \\
\hline Revúca & $23,70 \%$ & Kežmarok & $24,20 \%$ \\
\hline Kežmarok & $24,20 \%$ & Revúca & $25,30 \%$ \\
\hline Rimavská Sobota & $28,10 \%$ & Rimavská Sobota & $28,70 \%$ \\
\hline
\end{tabular}

Zdroj: Ústredie práce, sociálnych vecí a rodiny: Nezamestnanost' - mesačné štatistiky [online] [vid. 28. února 2016]. Dostupné z: www.upsvar.sk/statistiky/nezamestnanost-mesacne-statistiky.html?page_id=1254 


\subsection{Nezaměstnanost mladých}

Za rok 2014 vykazovalo Slovensko přes mírné zlepšení po překonání důsledků globální krize s 29,7 \% mezi státy Evropské unie 7. nejvyšší míru nezaměstnanosti mladých lidí do 25 let. Všechny členské státy Evropské unie sousedící se Slovenskou republikou vykazovaly nižší hodnoty tohoto indikátoru, nejméně Rakousko s 10,3 \%, dále Česká republika s 15,9 \%, Mad'arsko s 20,4 \% a slovenské hodnotě se nejvíce blížilo Polsko s 23,9 \%.

Při porovnání údajů o počtu ekonomicky aktivní populace do 25 let z Výběrových zjištování pracovních sil Statistického úřadu a počtech nezaměstnaných ve stejné kategorii z evidence Úřadů práce za období 1. až 3. čtvrtroku 2015 dostáváme orientační hodnoty míry nezaměstnanosti mladých, nejde tedy o oficiální statistiky, ale o dopočítané pozice na úrovni krajů. Tato čísla ukazuje tabulka 2.

Tabulka 2: Nezaměstnanost mladých do 25 let v krajích za období Q1-Q3 2015

\begin{tabular}{|l|c|c|c|c|}
\hline Území & $\begin{array}{l}\text { EAO } \\
\text { (v tisících) }\end{array}$ & $\begin{array}{l}\text { Nezaměstnaní } \\
\text { (v tisících) }\end{array}$ & $\begin{array}{l}\text { Míra nezam. } \\
\text { mladých }\end{array}$ & $\begin{array}{l}\text { Celková } \\
\text { evidovaná } \\
\text { míra nezam. }\end{array}$ \\
\hline Slovensko & 208,6 & 59,6 & $28,6 \%$ & $11,7 \%$ \\
\hline Bratislavský kraj & 19,2 & 2,9 & $15,3 \%$ & $6,0 \%$ \\
\hline Trnavský kraj & 23,7 & 4,2 & $17,8 \%$ & $7,7 \%$ \\
\hline Trenčiansky kraj & 19,2 & 4,9 & $25,8 \%$ & $8,8 \%$ \\
\hline Nitriansky kraj & 24,8 & 6,1 & $24,7 \%$ & $10,7 \%$ \\
\hline Žilinský kraj & 29,9 & 6,9 & $23,1 \%$ & $10,1 \%$ \\
\hline Banskobystrický kraj & 26,1 & 9,4 & $36,1 \%$ & $16,3 \%$ \\
\hline Prešovský kraj & 36,6 & 14,5 & $39,7 \%$ & $16,8 \%$ \\
\hline Košický kraj & 28,9 & 10,5 & $36,4 \%$ & $15,6 \%$ \\
\hline
\end{tabular}

Zdroj: Ústredie práce, sociálnych vecí a rodiny: Nezamestnanost' - mesačné štatistiky [online] [vid. 28. února 2016]. Dostupné z: www.upsvar.sk/statistiky/nezamestnanost-mesacne-statistiky.html?page id=1254; Štatistický úrad Slovenskej republiky: Databáza DATAcube: Ekonomicky aktívne obyvatel'stvo podl’a veku [online] [vid. 1. března 2016]. Dostupné z: datacube.statistics.sk/TM1WebSK/TM1WebLogin.aspx

Vypočítaná míra nezaměstnanosti mladých byla v loňském roce výrazně vyšší než míra evidované nezaměstnanosti celé ekonomicky aktivní populace za stejné období ve všech krajích. Nejpříznivější situace byla na západním Slovensku, v Bratislavském a Trnavském kraji, s 15,3\%, respektive 17,8\%. Následovala skupina ostatních západoslovenských krajů a Žilinského kraje, ve které se hodnota pohybovala okolo $25 \%$, tedy každý čtvrtý ekonomicky aktivní člověk do 25 let zde neměl zaměstnání. Nejvyšší nezaměstnanost mladých vykázaly Banskobystrický kraj a oba východoslovenské regiony, v rozmezí 36,1-39,7 \%, tedy $\mathrm{z}$ deseti ekonomicky aktivních mladých lidí zde jich téměř 4 byli nezaměstnaní. V porovnání s celkovou mírou nezaměstnanosti byla nezaměstnanost mladých vyšší v průměru 2,4 násobně za celé Slovensko, nejvíce se lišila v Trenčínském kraji, 2,9 násobně, nejméně 2,2 násobně v Banskobystrickém kraji, a všeobecně v tomto porovnání byly menší rozdíly v regionech s celkově vyšší mírou nezaměstnanosti.

Uchazeči do 25 let tvořili v minulém roce ve všech krajích významný podíl uchazečů o zaměstnání, za celé Slovensko se podíleli na počtu nezaměstnaných z 11,5\%, statistika neukazuje vztah mezi mírou evidované nezaměstnanosti a podílem mladých na ní, hodnoty jsou regionálně poměrně variabilní a neplatilo tak, že v krajích s vyšší nezaměstnaností by zároveň bylo více mladých nezaměstnaných. Na úrovni okresů je variabilita hodnot ještě výraznější. V okrese Rimavská Sobota s nejvyšší celkovou mírou nezaměstnanosti se na ní 
mladí do 25 let podíleli z 15,8 \%, co bylo méně než mediánový podíl mladých na celkové nezaměstnanosti v hodnotě $16,3 \%$. Nejvyšší podíly mladých se koncentrovaly při severní hranici Slovenska, bez diferenciace mezi východem a západem, v okrese Stará L'ubovňa to bylo 23,2 \%, v Tvrdošíně 22,9 \% a v Námestove 21,6 \%. Nad úrovní $20 \%$ se pohybovaly i další severní okresy, Kežmarok, Bardejov, Sabinov a Čadca. Naopak relativně nižší podíl mladých uchazečů o zaměstnání byl naměřený v okresech podél jižní hranice, 9,4 \% shodně v pátém a prvním bratislavském městském okrese, následovaných Košicemi III a Bratislavou III, tedy okresy s celkově nízkou mírou evidované nezaměstnanosti, na dalších místech ale byly okresy Poltár, Komárno a Rožňava, z nichž první a třetí měly celkovou nezaměstnanost naopak jednu z nejvyšších na Slovensku. Vyšší podíl mladých do 25 let v severních okresech nižší v jižních neodpovídá jejich zastoupení na celkovém ekonomicky aktivním obyvatelstvu.

Skupina nezaměstnaných mladých lidí z velké části překrývá se skupinou nezaměstnaných absolventi̊, tedy osob do 26 let, kteří ukončili vzdělávání před méně než dvěma roky a neměli placenou práci, i když tyto dvě skupiny nejsou identické. Absolventi se na celkové míře nezaměstnanosti podíleli na republikové úrovni z $6,3 \%$. Nejnižší podíl 2,6 \% tvořili v okrese Rimavská Sobota, kde byla celková nezaměstnanost nejvyšší, dále v okresech Revúca a Lučenec, tedy v okresech s vysokou celkovou nezaměstnaností. Nejvíce bylo absolventů mezi nezaměstnanými v okresech Námestovo a Tvrdošín, shodně 11,4 \%, a Púchov s 9,9 \%, a i další okresy s vysokým podílem absolventů měly celkovou nezaměstnanost spíše nižší. Analýza dat za všechny okresy vobrázku 3 ukazuje určitou vazbu mezi mírou nezaměstnanosti a podílem absolventů s naznačenou lineární regresí. Zjistili jsme vyšší podíl absolventů bez práce tam, kde je nezaměstnanost nižší, a naopak méně v okresech s vysokou mírou evidované nezaměstnanosti. Tento fakt může nepř́imo indikovat prŕíčinu vysoké nezaměstnanosti $\mathrm{v}$ těchto okresech právě $\mathrm{z}$ důvodu nízké nebo nevhodné vzdělanostní úrovně tak, že absolventi jako uchazeči s vyšším vzděláním nacházejí uplatnění rychleji než ostatní uchazeči.

Obrázek 3: Vztah podílu absolventů na nezaměstnanosti a celkové míry nezaměstnanosti v okresech

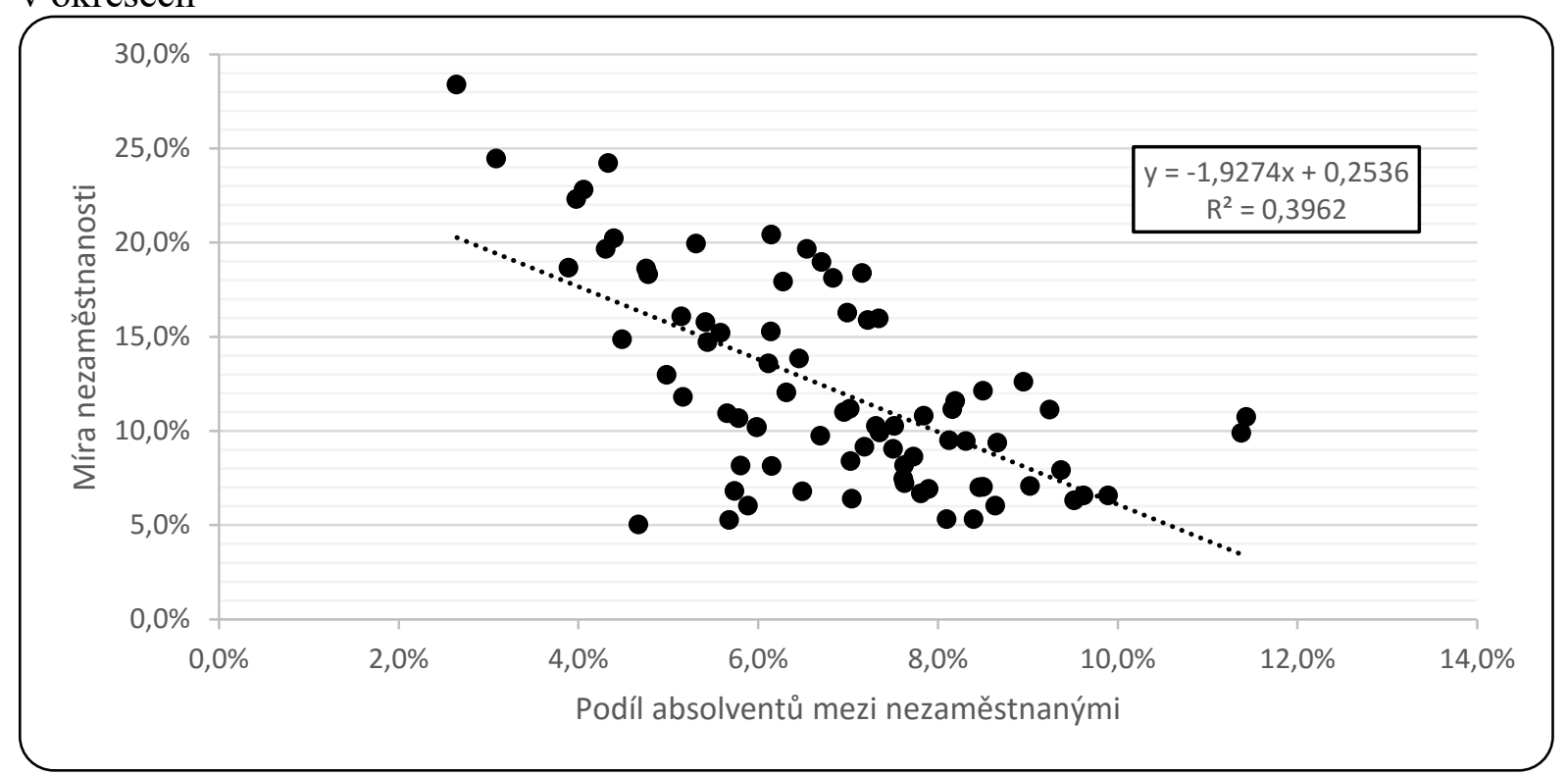

Zdroj: Ústredie práce, sociálnych vecí a rodiny: Nezamestnanost' - mesačné štatistiky [online] [vid. 28. února 2016]. Dostupné z: www.upsvar.sk/statistiky/nezamestnanost-mesacne-statistiky.html?page_id=1254 


\subsection{Nezaměstnanost ve vztahu $k$ regionální vzdělanostní úrovni}

Dosažené vzdělání do značné míry determinuje pozici jedince na trhu práce a platí, že zejména se základním vzděláním riziko nezaměstnanosti roste. Při analýze struktury nezaměstnaných podle dosaženého vzdělání je nutné hodnoty nezaměstnanosti porovnat se zastoupením jednotlivých vzdělanostních skupin vekonomicky aktivní populaci, které poskytují výsledky Sčítání obyvatel, domů a bytů z roku 2011, které sice nepokrývá srovnatelné časové období, ale pomáhá dokreslit proporcionalitu nezaměstnanosti v jednotlivých úrovních dosaženého vzdělání. V struktuře nezaměstnaných podle dosaženého vzdělání v minulém roce na Slovensku dominovali uchazeči s učňovským a středním odborným vzděláním, následovaní skupinou s úplným středním vzděláním s maturitou, spolu středoškoláci tvořili 60,4 \% všech uchazečů o zaměstnání. Zatímco nezaměstnanost osob s učňovským a středním odborným vzděláním tak přibližně odpovídá jejich zastoupení v ekonomicky aktivní populaci, u vyšších stupňů je nezaměstnanost nižší a u nižších stupňů naopak vyšší. Vysokoškolsky vzdělané osoby tvořili v roce 2011 19,8 \% ekonomicky aktivní populace, ale v roce 2015 jen 9,8\% uchazečů o zaměstnání, naopak lidé se základním vzděláním se podíleli na nezaměstnanosti z $24,2 \%$, ale v ekonomicky aktivní populaci jich bylo jen $8,5 \%$. V regionálním pohledu je specifická pozice Bratislavského kraje, kde je výrazně vyšší zastoupení vysokoškolsky vzdělané populace, 33,0 \% s prvním a druhým stupněm a 3,0 \% se třetím, ostatní regiony se pohybují blízko pod slovenskými průměrnými hodnotami $19,8 \%$ pro první a druhý stupeň a $1,1 \%$ pro třetí stupeň. Zejména v bratislavských městských okresech tak vysokoškoláci tvoří i významný podíl na struktuře nezaměstnaných, nejvíce s 41,1\% v okrese Bratislava I, co odpovídá jejich zastoupení v lokální populaci. Nejmenší podíl vysokoškoláků, mezi 2,5 \% a 3,2 \%, byl za loňský rok zjištěný v okresech Rimavská Sobota, Revúca a Kežmarok, tedy v okresech s nejvyšší nezaměstnaností, kde zároveň vysokoškoláci tvoří jeden z nejnižších podílů na ekonomicky aktivním obyvatelstvu na Slovensku. Ze statistik celkově vyplývá, že uchazeči se základním vzděláním měli vysokou míru nezaměstnanosti a tvořili nadproporcionální podíl nezaměstnaných, než by odpovídalo jejich zastoupení v ekonomicky aktivní populaci, nejvíce 3,8 násobek v okresech Košice I a Zvolen a 3,7 násobek v okresech Martin a Nové Mesto nad Váhom. Ve vyšších vzdělanostních stupních podíl nezaměstnaných v poměru k zastoupení stupně výrazně klesal, už skupina s učňovským a středním odborným vzděláním byla zastoupená přibližně rovnoměrně. Středoškoláci s úplným odborným nebo všeobecným vzděláním byli nezaměstnaní ve větší míře v okresech s vyšším podílem vysokoškoláků, tedy zejména v bratislavských a košických městských okresech. Vysokoškoláci byli zcela ve všech okresech zastoupeni mezi nezaměstnanými méně než v celé ekonomicky aktivní populaci.

\section{Vazba mezi nezaměstnaností a mzdami v regionech}

Nezaměstnanost a mzda jsou dvě určující charakteristiky trhu práce, a proto se zaměříme na jejich vzájemnou vazbu, s předpokladem, že úroveň nezaměstnanosti je jedním $\mathrm{z}$ determinantů výšky průměrné mzdy $\mathrm{v}$ regionu. Nezaměstnanost patří mezi faktory tlačící na nižší mzdy, zejména v regionech s její výrazně vyšší mírou. Statistiky dlouhodobě ukazují, že na Slovensku jsou mzdy v regionu hlavního města výrazně nadprůměrné a v ostatních regionech na nižší úrovni nivelizované v blízkosti národní průměrné mzdy. Jednoduché grafické znázornění vazby nezaměstnanosti a mezd s lineární regresí za rok 2014 ukazuje v obrázku 4 na úrovni krajů existenci tří skupin. Bratislavský kraj se profiluje jako samostatná skupina se současným výskytem relativně vysokých mezd a nízké nezaměstnanosti a potvrzuje tak v rámci Slovenska své specifické postavení. Př́íčinou je koncentrace ekonomických aktivit $\mathrm{v}$ hlavním městě, vysoký podíl vysokoškolsky vzdělané populace a vyšší výskyt zahraničních investic, zejména v oborech vyžadujících špičkovou specializaci a s vysokou přidanou hodnotou. 
Druhou skupinu tvoří ostatní kraje západního a jeden region středního Slovenska, konkrétně Trnavský, Trenčínský, Nitranský a Žilinský kraj. V těchto regionech jsou mzdy už výrazně nižší a pohybují blízko průměru celé republiky, s nezaměstnaností dosahující středních hodnot, přibližně mezi 8 a $11 \%$, s nejlepší pozicí Trnavského kraje benefitujícího z blízkosti k hlavnímu městu. Ve třetí skupině jsou mzdy podobné jako ve druhé, i když existuje větší rozpětí, ale tato skupina se vyznačuje vysokou nezaměstnaností, okolo 16-18 \%.

Obrázek 4: Vztah nezaměstnanosti a průměrné mzdy v regionech za rok 2014

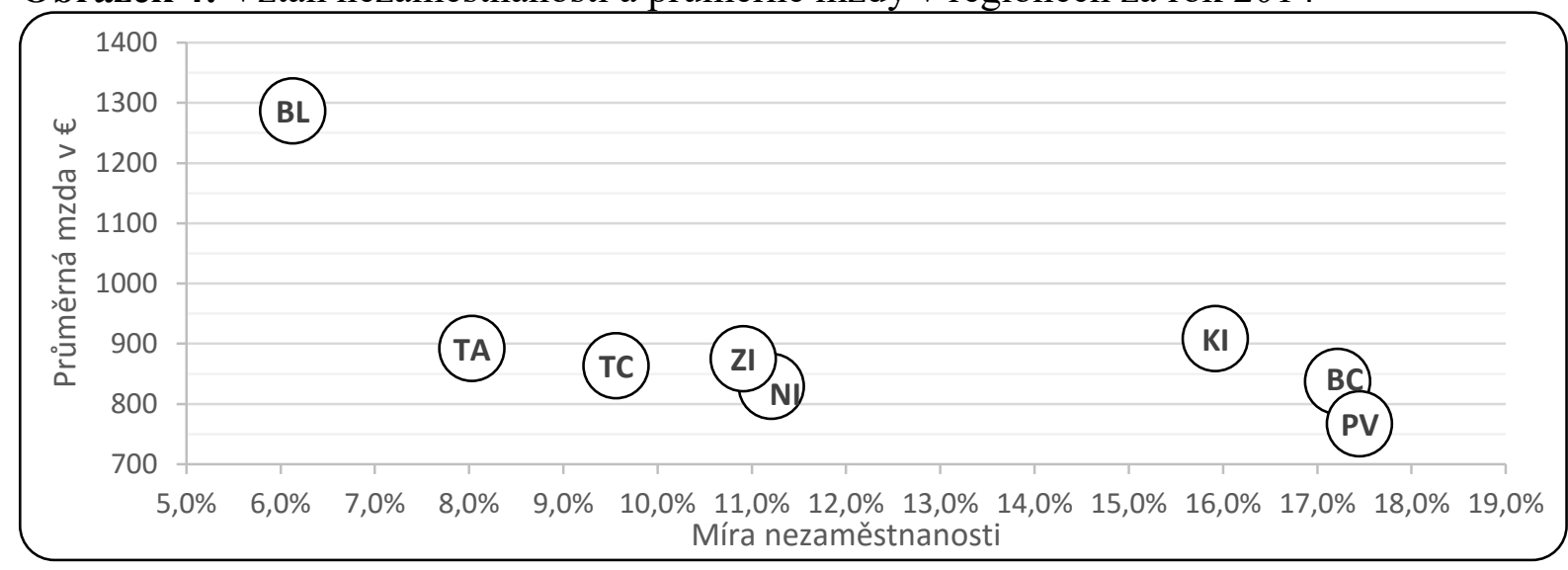

Zdroj: Ústredie práce, sociálnych vecí a rodiny: Nezamestnanost' - mesačné štatistiky [online] [vid. 28. února 2016]. Dostupné z: www.upsvar.sk/statistiky/nezamestnanost-mesacne-statistiky.html?page_id=1254; Štatistický úrad Slovenskej republiky: Databáza DATAcube: Mzdy podla ekonomickej činnosti zistené pracoviskovou metódou [online] [vid. 25. února 2016]. Dostupné z: datacube.statistics.sk/TM1WebSK/TM1WebLogin.aspx

V evropském srovnání vychází Slovensko jako stát s jedním z nejnižších podílů minimální mzdy na průměrné mzdě (Eurostat, 2016b). V roce 2014 to bylo 35,4 \% a ze států se zveřejněnými daty (tedy zejména státy s legislativně určenou a definovanou minimální mzdou) měla nižší hodnotu ukazatele pouze Česká republika, průměr celé Evropské unie byl $42,2 \%$, ale ve dvou státech, konkrétně v Lucembursku a ve Slovinsku, tento podíl přesáhl $50 \%$. Přestože v evropském porovnání jde o relaci k průměrné mzdě a ne mediánu, který by lépe zohledňoval mzdové nerovnosti, je zřejmé, že za Slovensko jako celek jde o nízkou hodnotu a může se zdát, že centrálně určená výška slovenské minimální mzdy nemá vliv na vysokou nezaměstnanost.

Jinak ale vypadá detailní pohled na situaci $\mathrm{v}$ okresech vzhledem na diferenciaci průměrné mzdy za rok 2014. Vysoká průměrná mzda v Bratislavě stlačuje hodnotu ukazovatele na 25-29 \% a všech 5 bratislavských okresů je tak jako jediných pod hodnotou $30 \%$. Naopak 9 okresů východního a středního Slovenska překračuje hodnotu $50 \%$, nejvíce okres Bardejov s 57,3 \% podílu minimální mzdy na průměrné, a dalších 26 okresů se této hranici blíží s hodnotami vyššími než $45 \%$. Až 46 okresů potom má hodnotu indikátoru vyšší než evropský průměr, tedy $42,2 \%$. Vazbu podílu minimální mzdy na průměrné a nezaměstnanosti potvrzuje obrázek 5. Data ukazují vzájemný vztah obou jevů, lineární regrese nižším koeficientem determinace naznačuje vliv jiných proměnných, zejména pro vyšší hodnoty podílu, přesto je určitá vazba zřejmá. Minimální mzda se tedy z regionálního pohledu jeví jako nástroj, který může ovlivňovat nezaměstnanost zejména $\mathrm{v}$ oblastech $\mathrm{s}$ nízkou mzdovou úrovní. Vzniká otázka, zda by nebylo vhodné minimální mzdu diferenciovat regionálně ve vazbě na místní průměrnou mzdu a zejména ve vztahu k nezaměstnanosti. Hladina takové diferencované minimální mzdy by však vokresech s vysokou nezaměstnaností narážela na koncept sociálně ochranné funkce minimální mzdy, tedy takové mzdy, která zaručuje důstojný prř́jem chránící před chudobou. Navíc v některých okresech je nezaměstnanost velmi 
nízká i přes nízkou průměrnou mzdu, např́klad v okrese Galanta s 5,4 \% nezaměstnaností a indikátorem 45,8 \%, v okrese Bardejov je naopak hodnota indikátoru nejvyšší, ale okres nepatří mezi nejvíce postižené vysokou nezaměstnaností.

Obrázek 5: Vztah nezaměstnanosti a poměru minimální mzdy na průměrné mzdě v okresech za rok 2014

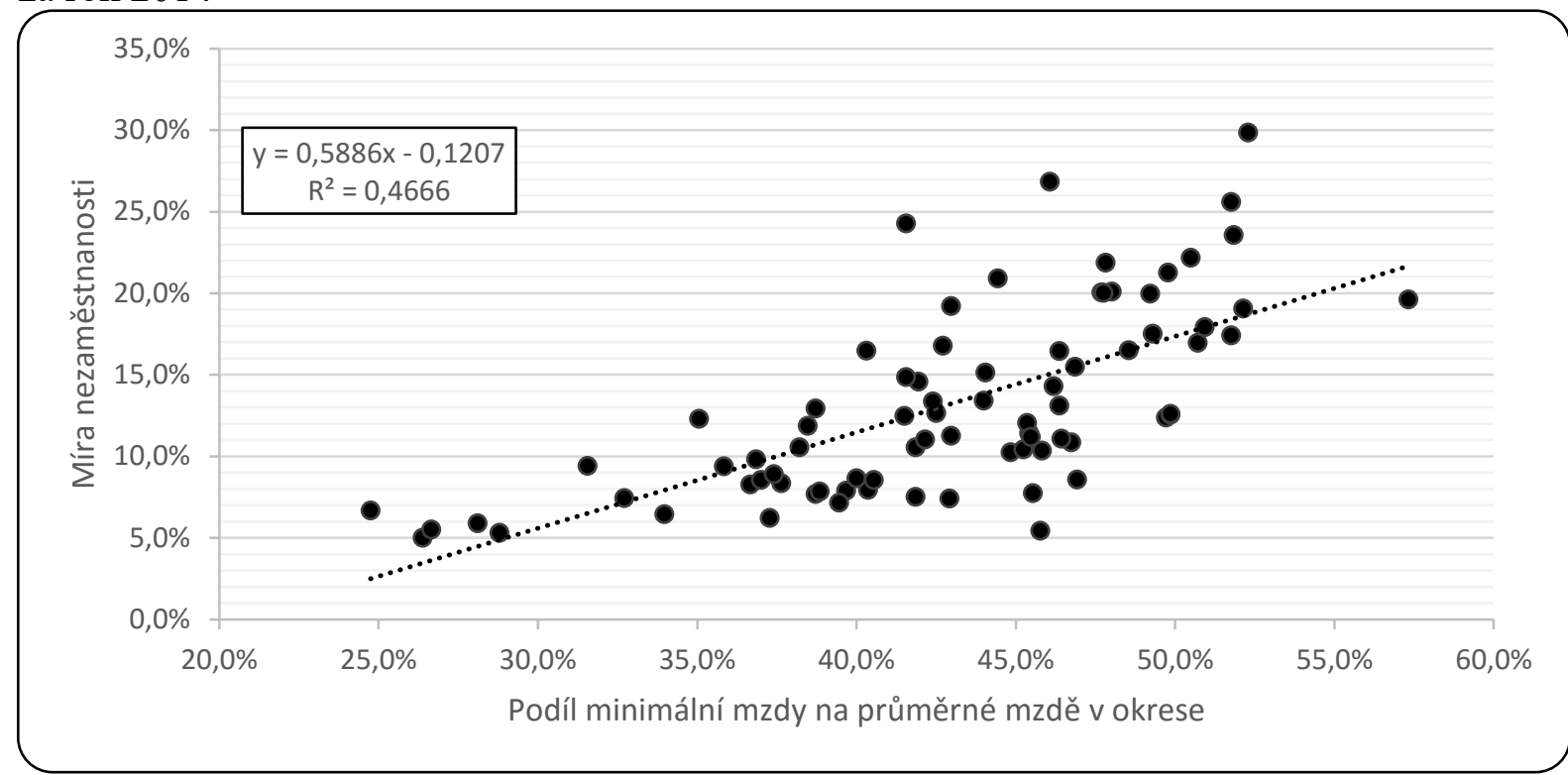

Zdroj: Ústredie práce, sociálnych vecí a rodiny: Nezamestnanost' - mesačné štatistiky [online] [vid. 28. února 2016]. Dostupné z: www.upsvar.sk/statistiky/nezamestnanost-mesacne-statistiky.html?page_id=1254; Štatistický úrad Slovenskej republiky: Databáza DATAcube: Mzdy podla ekonomickej činnosti zistené pracoviskovou metódou [online] [vid. 25. února 2016]. Dostupné z: datacube.statistics.sk/TM1WebSK/TM1WebLogin.aspx

\section{Závěr}

Nezaměstnanost jako taková je na Slovensku přetrvávajícím problémem s výraznými socioekonomickými dopady a v celoevropském měřítku je pozice Slovenska ve statistikách nezaměstnanosti přes mírné zlepšení spíše horší. Míra nezaměstnanosti však není na Slovensku distribuovaná rovnoměrně, naopak je výrazně prostorově diferencovaná ve vazbě na ekonomickou výkonnost nebo strukturu obyvatelstva. Tyto charakteristiky determinují lokální pracovní trhy na úrovni krajů a zejména okresů, které se tak vyznačují specifickou strukturou pracovní síly, jejíž míra využití a využitelnosti v lokálním hospodářství se projevuje na jedné straně specifickou lokální mzdovou úrovní a na straně druhé lokální mírou nezaměstnanosti.

Výraznou diferenciaci nezaměstnanosti na Slovensku potvrzují výsledky všech provedených analýz statistik okresní míry evidované nezaměstnanosti za rok 2015. Rozdíly rostou nepravidelně na ose západ - východ, zcela nejnižší hodnoty jsme zjistili v Bratislavě následované Trnavským krajem, který profituje $\mathrm{z}$ blízkosti $\mathrm{k}$ hlavnímu městu, na hodnotách do $10 \%$ se pohybovaly okresy s ekonomickými centry, tedy průmyslová považská města v Trenčínském kraji, Žilina a Martin v Žilinském kraji, Nitra a Šala v Nitranském kraji, košické městské okresy i Banská Bystrica a Zvolen v Banskobystrickém kraji. V periferních okresech východního a jihu středního Slovenska ale byla nezaměstnanost velmi vysoká, mezi tři okresy s její nejvyšší mírou patřily v loňském roce Rimavská Sobota, Revúca a Kežmarok. Vysoká nezaměstnanost se váže kromě periferního postavení i na nedostatečnou infrastrukturu, která odrazuje investory i přes nízkou cenu práce, a na nevhodnou strukturu uchazečů o zaměstnání. Jde zejména o vzdělanostní úroveň, okresy s vysokou nezaměstnaností jsou charakteristické vyšším zastoupením osob se základním vzděláním mezi 
ekonomicky aktivní populací a tato skupina zároveň v problémových okresech tvoří nejvyšší podíl nezaměstnaných, co vede k situaci, že v nejvíce postižených okresech je až každý druhý ekonomicky aktivní člověk se základním vzděláním bez práce. Pro řešení je nutné hledat komplexní přístupy k změně vzdělávacího systému, zejména zvýšení spolupráce mezi zaměstnavateli a školami, ale i v maximální míře bránit předčasnému přerušení školní docházky a podpoře dalšího studia po skončení základní školy. Dalším negativním jevem je nezaměstnanost mladých do 25 let, která je na rozdíl od celkové nezaměstnanosti diferencovaná na ose sever - jih, koncentruje se v okresech podél severní hranice bez větších rozdílů mezi východem a západem.

Problémem při obsazování volných pracovních míst je nízký počet pozic vyžadujících nejnižší kvalifikaci, na které jsou často přijímáni uchazeči s kvalifikačním profilem př́evyšujícím požadavky, čím dochází $\mathrm{k}$ vytláčení nekvalifikovaných $\mathrm{z}$ trhu práce. $\mathrm{V}$ opatřeních politiky trhu práce je třeba zaměřit se $\mathrm{z}$ krátkodobého hlediska na tvorbu vhodných pracovních míst odpovídajících vzdělanostní úrovni nezaměstnaných a zabezpečit jejich rekvalifikaci podle aktuálních potřeb zaměstnavatelů, z dlouhodobého hlediska je nutná užší spolupráce vzdělávacího systému ze zaměstnavateli pro zajištění požadované vzdělanostní struktury mladých lidí vstupujících na trh práce.

Ve vztahu k úrovni průměrné mzdy se neukázala silná vazba, jen se potvrdila ekonomická dominance Bratislavského regionu s výrazně nadprůměrnou mzdou a velmi nízkou nezaměstnaností, v ostatních krajích se při středních i vysokých mírách nezaměstnanosti byly rozdíly v průměrné mzdě komprimované na úzké pásmo blízko národní průměrné mzdy. Určitý vztah ukazuje porovnání nezaměstnanosti $\mathrm{k}$ indikátoru podílu minimální mzdy na místní průměrné mzdě, který vychází z předpokladu, že př́liš vysoká minimální mzda má negativní dopad na trh práce, protože zaměstnavatelé nejsou při dané mzdové úrovni ochotní zaměstnávat dodatečnou pracovní sílu. Analýzou jsme zjistili určitou slabší vazbu mezi těmito dvěma jevy, platí tedy, že vyšší míra nezaměstnanosti se často spojuje s vyšším podílem minimální mzdy na průměrné mzdě v okrese.

\section{Poděkování}

Příspěvek vznikl v rámci řešení výzkumného projektu VEGA č. 1/0001/16 „Súčasnost’ a perspektívy zmien zamestnanosti a súvisiacich procesov $\mathrm{v}$ kontexte naṕn̆ania cielov Európskej stratégie zamestnanosti““.

\section{Literatura}

[1] ČAPLÁNOVÁ, A. a M. MARTINCOVÁ, 2014. Inflácia, nezamestnanost' a l'udský kapitál z makroekonomického pohl'adu: teoretické a praktické problémy. 1. vyd. Bratislava: Wolters Kluwer. ISBN 978-80-8168-024-3.

[2] EUROSTAT, 2016a. Long-term unemployment by sex - quarterly average, \% [online]. [vid. 27. února 2016]. Dostupné z: ec.europa.eu/eurostat/data/database

[3] EUROSTAT, 2016b. Monthly minimum wage as a proportion of average monthly earnings (\%) [online]. [vid. 28. února 2016]. Dostupné z: ec.europa.eu/eurostat/data/database

[4] INŠTITÚT FINANČNEJ POLITIKY, 2016. Malý vplyv zvyšovania minimálnej mzdy na nezamestnanost' [online]. [vid. 4. března 2016]. Dostupné z: www.finance.gov.sk/Default.aspx?CatID $=10571$

[5] MAREŠ, P., 1994. Nezaměstnanost jako sociální problém. 1. vyd. Praha: Sociologické 
nakladatelství. ISBN 80-901424-9-4.

[6] PAUKOVIČ, V., 2007. Problém nezamestnanosti - vybrané makrosociologické a mikrosociologické kontexty. Sociálne a politické analýzy, 1(1), 73-101. ISSN 13375555 .

[7] RIEVAJOVÁ, E. a kol., 2012. Trh práce a politika zamestnanosti. 1. vyd. Bratislava: Vydavatel'stvo EKONÓM. ISBN 978-80-225-3544-1.

[8] SCHULTZ, T. W., 1961. Investment in Human Capital. The American Economic Review. 51(1), 1-17. ISSN 0002-8282.

[9] SLOVENSKO.SK. Evidenčné čísla motorových vozidiel [online]. [vid. 13. července 2016]. Dostupné z: www.slovensko.sk/sk/agendy/agenda/_evidencne-cisla-motorovychvozid

[10] ŠTATISTICKÝ ÚRAD SLOVENSKEJ REPUBLIKY, 2016a. Databáza DATAcube: Ekonomicky aktivne obyvatel'stvo podl'a veku [online]. [vid. 1. března 2016]. Dostupné z: datacube.statistics.sk/TM1WebSK/TM1WebLogin.aspx

[11] ŠTATISTICKÝ ÚRAD SLOVENSKEJ REPUBLIKY, 2016b. Databáza DATAcube: Miera evidovanej nezamestnanosti [online]. [vid. 25. února 2016 a 14. července 2016]. Dostupné z: datacube.statistics.sk/TM1WebSK/TM1WebLogin.aspx

[12] ŠTATISTICKÝ ÚRAD SLOVENSKEJ REPUBLIKY, 2016c. Databáza DATAcube: Mzdy podl'a ekonomickej činnosti zistené pracoviskovou metódou [online]. [vid. 25. února 2016]. Dostupné z: datacube.statistics.sk/TM1WebSK/TM1WebLogin.aspx

[13] ŠTATISTICKÝ ÚRAD SLOVENSKEJ REPUBLIKY, 2016d. Databáza DATAcube: Obyvatel'stvo podl'a trvalého pobytu, pohlavia, dosiahnutého vzdelania, ekonom. aktivity, odvetvia ekonom. činnosti, štátnej príslušnosti a veku [online]. [vid. 2. února 2016]. Dostupné z: datacube.statistics.sk/SODB/TM1WebLogin.aspx

[14] UNECE. UN/LOCODE Country Subdivisions ISO 3166-2 [online]. [vid. 13. července 2016]. Dostupné z: www.unece.org/fileadmin/DAM/cefact/locode/Subdivision/ skSub.htm

[15] ÚSTREDIE PRÁCE, SOCIÁLNYCH VECÍ A RODINY, 2016. Nezamestnanost' mesačné štatistiky [online]. [vid. 28. února 2016]. Dostupné z: www.upsvar.sk/statistiky/nezamestnanost-mesacne-statistiky.html?page_id=1254 